\title{
A Preliminary Exploration of Chinese Traditional -Wa Element Tectonic Culture in Contemporary Context
}

\author{
Li Jiaying \\ SEU (Southeast University) \\ China
}

\begin{abstract}
Wa(瓦), a kind of traditional tile in China, contains Chinese traditional cultural connotation and national sentiments. After the industrial revolution, cause of collisions with foreign cultures, how to find a proper tectonic for wa under contemporary context has become a heat topic for many Asianarchitects. This article attempts to analyze traditional tectonic logic of Wa, its status in historical culture and contemporary plights, through the analyze of four contemporary architects'( Wang Shu, Kengo Kuma, Zhang Yonghe, Qian Qiang) most representative practical experience of wa to study the possibility of tectonic culture about wa element under contemporary context.
\end{abstract}

Keywords: Wa, contemporary context, tectonic culture

\section{The traditional tectonic logic of Wa, its status in Chinese culture and its culture meaning}

"Wa, a general terms of all earthenware that been baked, is a photographic character." Wa is used to be c alled by a joint name of ceramic, as time goes by, it has gradually become a component of roof. And durin $g$ quite a long time, the fine grey tiles as roofing covered Chinese conventional architectures, also as a she lter for Chinese ethnic peoples. As a symbol of history, culture and people's status, as well as a reflection of China's unique living culture, little by little, wa has become a part of Chinese culture, meanwhile beari ng people's feelings and memories.

\subsection{The traditional tectonic logic of Wa and its status in Chinese culture}

Long before Western Zhou Dynasty, wa roofing (瓦屋面) has appeared, and plate tiles of Western Zhou Dynasty have been excavated in the historical sites of Western Zhou Dynasty like Fu Feng, Ke Shengzhuang in Shaanxi Province. The appearance of using Wa shows that it is a big progress in roofing engineering. After that, tile-work (瓦作) ${ }^{1}$ is constantly evolving in terms of waterproofing and fixation.(Chart 1)

\section{Chart 1.Development of tiles in waterproofing and fixation}

\begin{tabular}{|c|c|c|c|c|c|}
\hline & & $\begin{array}{l}\text { Western } \text { Zhou } \\
\text { Dynasty }\end{array}$ & $\begin{array}{l}\text { Qin and Han } \\
\text { Dynasties }\end{array}$ & Song Dynasty & Ming and Qing Dynasties \\
\hline $\begin{array}{l}\text { Waterp } \\
\text { roof }\end{array}$ & $\begin{array}{l}\text { Plate tile } \\
\text { roofing }\end{array}$ & & & $\begin{array}{l}\text { Covered } 40 \% \\
\text { of each } \mathrm{Wa} \text {, } \\
\text { to drain away } \\
\text { the rain }\end{array}$ & $\begin{array}{l}\text { Covered } 70 \% \text { of each Wa, or covered } 60 \% \\
\text { of each Wa, to control the leakage among } \\
\text { tile gaps, and to promote the water- } \\
\text { proof performance of roofing }\end{array}$ \\
\hline & Eaves tile & $\begin{array}{l}\text { Semicircle, } \\
\text { eaves tile and } \\
\text { the tile wall are } \\
\text { formed a right } \\
\text { angle }\end{array}$ & $\begin{array}{l}\text { round, eaves tile } \\
\text { and the tile wall are } \\
\text { formed a bevel, to } \\
\text { prevent the rain } \\
\text { reflow }\end{array}$ & & \\
\hline Fixation & & $\begin{array}{l}\text { bonding } \\
\text { materials, tile } \\
\text { nail, etc. }\end{array}$ & Mud bonding & lime & $\begin{array}{l}\text { Lime. tile nail, there are plenty kinds of the } \\
\text { heads of tile nails, such as acorn top made } \\
\text { by colored glaze, medal tile nails, they are } \\
\text { fabulous. }\end{array}$ \\
\hline
\end{tabular}

${ }^{1}$ 瓦作Tile-work, which means roofing engineering operation in ancient China. It is listed as one of of architecture construction systems. It first appeared in Western Zhou Dynasty. 
The most original roofing works in China is using grass and mud to make roofs, also is the most original waterproof measures. The appearance of Wa marks a great leap forward in roofing engineering. In the early Western Zhou Dynasty, there were only flat tiles existed, no sign of round tiles (筒瓦). At the very beginning, people only use "yangwa" (仰互) ${ }^{2}$ to build roofing, to prevent leakage of rain from the tile ridges(瓦猆), so people used stalks to fill the gap between wa, then pave wa, and this invention has still been in use in some folk houses today. In the late Western Zhou Dynasty, round tiles emerged, and were used in offical architecture ( 官式建筑) such as halls, pavilions, pavilion on terrace, temples, Taoist temples, etc. Because of the leakage gap in the connection of the round tiles, the joints of wa have been constantly evolving. In the period of Spring and Autumn and the Period of Warring States, the margin of the round tile(“瓦唇') is a declivitous slash shape or a slash-curved shape, and part of the rain will easily leak through the margin of round tile into the roof. After Han Dynasty, the margin of the round tile forms a semicircular groove along the direction of the round tile arc line, which means that a small amount of rain will leak from the seam crossing between round tiles, and lead a small amount of rain seeps down from the crevice of the round tile; it also flows along the semi-circular groove of wa's margin to flat tiles, avoiding the situation as water seeping down to the roof in the Spring and Autumn and Warring States Periods. During Qing Dynasty, the margin of the round tile had been tremendously developed on the basis of Han Dynasty. The evolution of eaves tile is also about waterproofing. The most original eaves tile in Western Zhou Dynasty was semicircular, and gradually developed into a circle in Qin and Han dynasties, thus the joint of tile and eaves tile turned a right angle into a bevel angle. For one thing, the water controlling of round eaves tiles are much better than semicircle eaves tiles. Besides, to make the right angle into a bevel, the rain will not easily reflow. In Song dynasty, while the book called Yingzao Fashi (营造去巧 $)^{3}$ said that the overlap between the top and bottom tiles accounts for $40 \%$ of the entire Wawhile expose $60 \%$ of the rest(国西露分). To compare with cover $60 \%$ of each Wa or cover $70 \%$ of each Wa in Qing Dynasty, the safety coefficient of waterproof for the former type is not that satisfying. Once some certain bottom tile is broken, the water will leak to the basement layer of roofing. However, there are three Wa overlapping in Qing Dynasty, for example, Wa B aboves and covers $30 \%$ or $40 \%$ of $\mathrm{Wa} \mathrm{A}$, then Wa C lays on Wa B also covers $30 \%$ or $40 \%$ of $\mathrm{Wa} \mathrm{B}$. Based on this, even one bottom tile breaks, the rain will not leak. This could raise the safety level. Moreover, bottom tiles in Qing Dynasty are wider than Song Dynasty's. It helps to prevent rain overflow, and to promote continuous improvement of roofing waterproofing facilities.

The fixation of Wa is an important aspect of tile-work. As can be observed from wa unearthed in the western zhou in the provinces, the main tiles in the western zhou were plate tiles with a relatively large size, which generally had tile nails(瓦钉) and tile rings(瓦环). There is also a tile nail has been found in the corner of a broken piece of the ridge tile. The concave and convex surfaces of flat tile as the tile nail and the tile ring showed that to fastened wa craftsmen used two ways at that time. One is the roof made similar bottom layer as "shanbei" (苫背) ${ }^{4}$; the other is the "lengtan"(冷售 ${ }^{5}$ roofing without "shanbei", using ropes to run through tile rings to make it fastened. It is noteworthy that all the "yangwa" are horizontal rings and all the "hewa"(合瓦) are vertical rings. Therefore, it can be inferred that the binding structure of "yangwa","hewa" and rafters. In the Spring and Autumn Period, the use of wa was not widespread, but gradually increased in the late Spring and Autumn Period and the Warring States Period. In the Kingdom of Luoyang, Jin Capital of Houma, Qi Capital of Linzi, Lu Capital of Qufu, Zhao Capital of Handan, Yanxia Capital of Yi county, and other sites, all left a considerable quantity of wa. The size of wa in Warring States Period are normally quite large. The largest round tile unearthed from Lao Laotai(老始台) in Yanxia Capital is $91 \mathrm{~cm}$ long and $51 \mathrm{~cm}$ wide. During Warring States Period, there was an important breakthrough in the construction of wa, which was to separate the tile nail from the its body. This was not only effectively strengthened the consolidation of wa, but also simplified the production of the mold which can make tiles(瓦坯).

\footnotetext{
2仰互. It means concave surface of wa faces upside.

${ }^{3}$ The Yingzao Fashi (Chinese: 營造法式; pinyin: yíngzàofãshì; literally: "Treatise on Architectural Methods or State Building Standards") is a technical treatise on architecture and craftsmanship written by the Chinese author Li Jie (李誡; 10651110),[1] the Directorate of Buildings and Construction during the mid Song Dynasty of China.

4苫背:When people build houses, they wipe ashes and mud on straw or mat, then make the bottom layer of the roof.

5冷挑侄面: The bottom tiles are directly put on the tile roofing above rafter.
} 

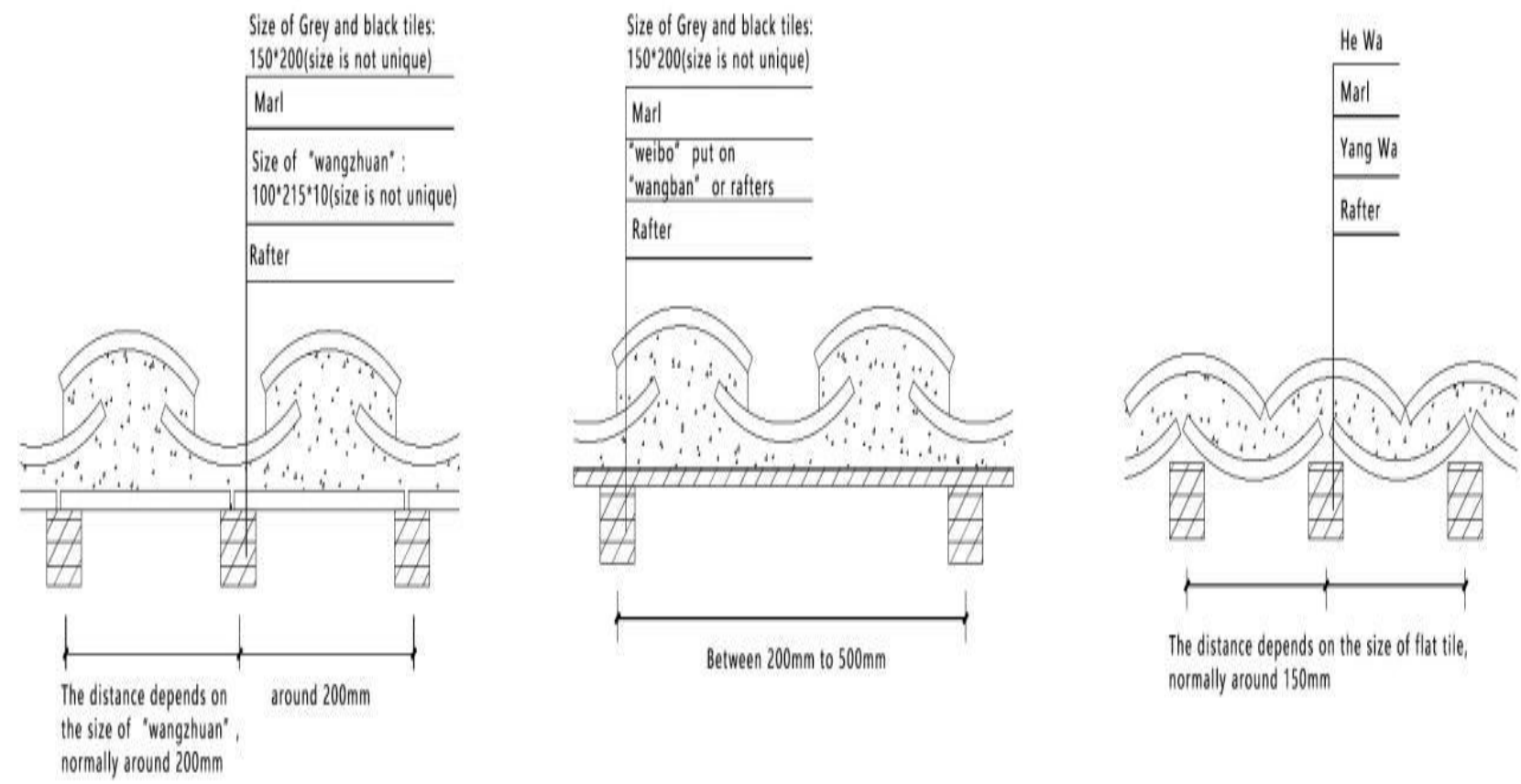

Figure1 Regular Practice of Pitching tiles Roofing (auther's own painting)

Due to different climate, there is a slight difference in the fabrication of tile roofing between the north and the south. Generally, after done with the wall, craftsmen place the purline along the open side first, then pave a rafter with gradient in its top edge to the depth. Above the rafter, craftsmen “wangzhuan”(望专), “wangban”(望板), “weibo"(苇箔) and the foundation made from the "shanbei”(苫背), to prevent rain, insulate heat and to make a close space for the roofing at the same time. In the end, to pave one Yin and one Yang flat tile as a gutterway(Figure 1), and use cover tile(盖瓦) or black brick to finish engineering on the ridge. The shape of flat tile looks like a trapezoid, one side is larger than the other. This unparalleled feature which can stop wa from slipping, which is useful in south China. Due to the water shortage in the north, many folk houses are only covered with ashes instead of covered with Wa, which is quite different from south China area.

\subsection{Cultural meaning of Wa}

In fact, Wa was also involved in the social system of ancient Chinese culture. The first official use of the word "tile-work" was in Yingzao Fashi of Song Dynasty, where "tile-work" has been listed in one of the building construction systems, also it systematically and completely summarizes the imperial building systems of Tang and Song dynasties such as architectural design, construction, materials, and laboring, etc. The tile-work system in Yingzao Fashi has been divided in five parts, tile paving system(铺瓦制度), executing basement under wa(瓦下基层施工), building ridges(垒冷), using chiwei (鸱尾), using beast head(用兽头). Each part has been ranked in monumental halls, pavilions, xiewu(挟屋), corridor rooms(廊屋 $\left.{ }^{0}\right)$, pavilions and pavilions on terrace $\left(\right.$ 亭榭 $\left.^{1}\right)$.

\footnotetext{
${ }^{6}$ 望专.Splits paved on rafters, used to bear tiles, to prevent the rain, wind blow, and dust from corrugation of wa. Also make the top of interior looks smooth and level.

${ }^{7}$ 鸱尾: Chiwei, As a decorative building component that appears on the main and vertical ridges of the roof of the imperial buildings, each of which has different shapes and names. The size of its shape and the number can represent the level of the palace.

${ }^{8}$ 兽头:Sculptures placed on the spine of a house, a palace, etc, which were in ancient Chinese traditional architecture.

挟屋A small building attached to the side of a large building.

${ }^{10}$ 廊屋A passageway under the eaves or a separate passageway with roof
} 
Later, Yingzao SuanLi ${ }^{12}$ in Qing Dynasty recorded the fabrication and usage stipulation of tile-work in formal mode and folk mode. The formal mode mostly used in palaces, mausoleums, temples and the folk mode always used in civilian houses. The Wa system is becoming more and more mature in the construction rules issued by the various dynasties, and Wa has become a symbol of social status.

Chinese ethic peoples have deep feelings for eaves tile. As early as Qin Dynasty, eaves tile was engraved with ordinary people or royal noble's daily life or hunting scenes, eaves tile carries human beings' expectations and civilization (Figure 2). Because of the special feelings for eaves tile, people created paper and handiwork which related to it. Wa, as it were, for the Chinese ethic peoples has been more than just a common material of roof. It is a kind of culture for us to carry wishes and hopes. It carries through the wind and the rain, it passes down identity and desire, it spreads thousands of years of culture and long-cherished wishes, it communicates irreplaceable emotions, and finally, it has a part of Chinese cultural spirit.
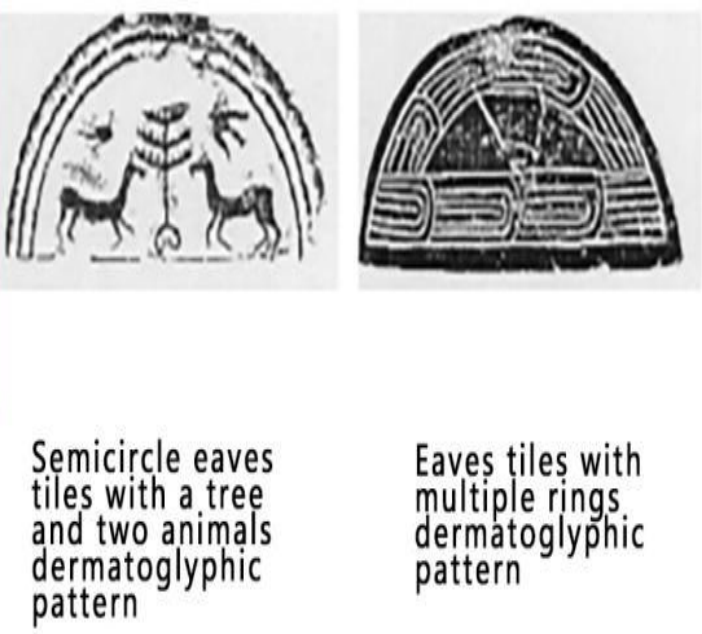

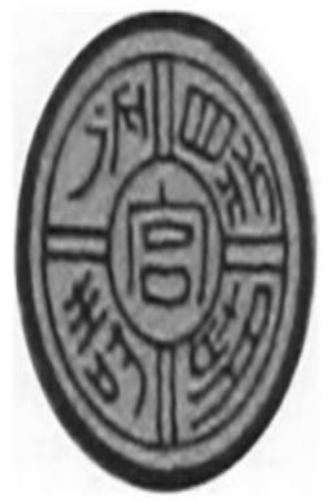

Eaves tiles with multiple rings dermatoglyphic pattern

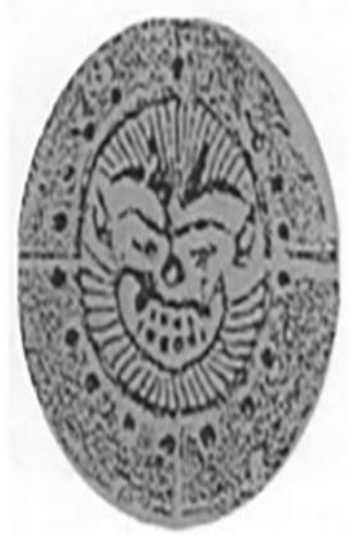

Eaves tile with beast mask design, Southern and Northern Dynasties

Figure2Regular Practice of Pitching tiles Roofing

\section{Contemporary Plight of traditional Tile-work}

Since the industrial revolution, the productive forces have been greatly developed, and science and technology have made rapid progress, which leading mankind into a new era. The way people understand and use materials has changed dramatically. Steel, cement, concrete and other new materials have got people's attention, and gradually become mature, replace traditional materials and turn into the main strength of materials in architecture and construction. On the contrary, compared with modern materials, the development of traditional tile-work has its own dilemma.

(1)Limitations of Production: manufacture for most of the traditional wa industries still follows the traditional manual workshop mode, which is not conducive to a large scale production.

\footnotetext{
${ }^{11}$ 亭榭, wide-open structure building in ancient China. Pavilions are often built along the road for pedestrians to rest, enjoy the cool or view scenes. Ting, means a pavilion is generally a wide-open structure. Xie, means a building built near water, partly or wholly above water, for people to rest and enjoy the view.

${ }^{12}$ Yingzao Suanli(Chinese:营造算例):As the appendix of Qingshi Yingzao Zeli which published in 1934 by China Construct Society. In the early 1930s, Liang Sicheng sorted out the transcripts of Shushu(术昘) such as "Yinglv Damu Zuofa" and "Damu Fenfa" according to Jiangzuo Zeli of Qing Dynasty handed down by Chinese architecture craftsmen in the past dynasties.
} 
(2)Limitations of properties: The physical properties of traditional wa can no longer meet the requirements of present buildings. Wa roofing is against today's aseismic design, and it can't compete with modern materials on aspect of waterproofing.

(3)Limitations of execution of works: compared with modern materials, traditional tile-work construction seems more complex. The size of $\mathrm{Wa}$ is small, only suitable for manual construction. However, such mode of construction proceeds slowly and usually requires a lot of human labour. As for traditional buildings such as folk houses, the problem is not serious because of their small size, but there are difficulties in applying this to modern public buildings of larger size.

(4)Limitations of lifetime: Wa is easily broken. However, the connection between wa is also not strong enough. Compared with modern materials, the service life of Wa is relatively short, which is easily affected by the outdoor environment and can affect the use and lifetime of buildings.

\section{Exploration of Wa-element's Tectonic Culture in Contemporary Context}

In the contemporary context, physical attributes of Wa may no longer be the advantage by era, but the emotional and cultural spirituality that contained within it cannot be dispelled. Architecture is the experience of real life, which not only reflects the Times, but also bears the cultural characteristics of historical tradition. It is a manifestation of human spirit. Wa, a traditional material element bearing special cultural connotation, has become the most direct and effective container of Chinese architectural spirituality with its material basis. Kenneth Frampton advocates the integration of traditional and modern architecture, and to delivery historical culture based on modern material and customs, instead of simply returning to the tradition. Chinese architects have been exploring the issue of inheriting traditional values and architectural culture. "Tectonic", a word related to materials and build, also contains the emotion and memory of people. Kenneth Frampton said construction is the bridge between traditional and modern times. In recent years, many architects try to blend wa element into modern design and explore its construction mode in the contemporary context.

\subsection{Exploration of Traditional Chinese spirituality in wa's tectonic culture by traditional tile-work}

Kenneth Frampton thought that there is a thing called empathy, or sympathy, between people and objects, similar to metaphor. On the basis of fully understanding the construction status and background, the material seems to have thoughts and emotions, and people also get strong emotional feedback. Traditional materials with their collective memory, nostalgia experience, unique site spirit and traditional culture, reflect the site and timeliness of the building. As a material that has existed for hundreds of thousands of years, Wa has become the cultural spiritual sustenance of people.

Wang Shu won Pulitzer Prize in 2012, his application of the traditional architectural element of old wa gave new vitality to wa. In 2005, at Xiangshan Campus of CAA, Wang Shu first tried to collect 3 million pieces of old wa from different eras, which covered the roofs of teaching buildings, libraries and sports stadiums with large coverage, as well as the diagonal sunshade of the building elevation with old Wa embedded in new walls(Figure 3). At THE VENICE BIENNALE of 2006, Wang Shu's installation named "TILES GARDENS," constructed a traditional Chinese image which used 60 thousandsold wa which across the ocean. In front of a row of green trees, Wang Shu built an 800 square meter tilting Wa roof with a zigzag bamboo bridge from the ground to it(Figure 4).

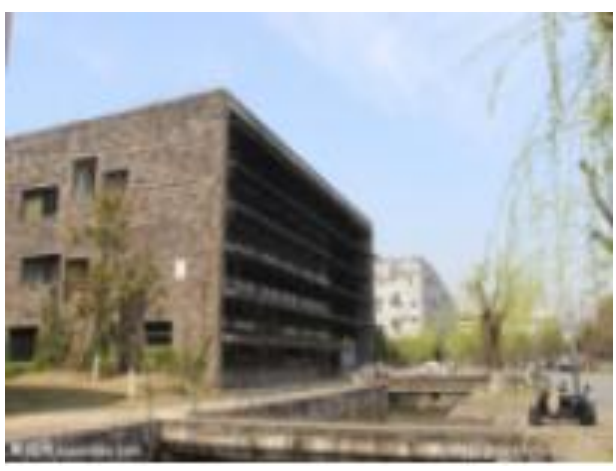

Figure 3 No.12 Xiangshan Campus, CAA

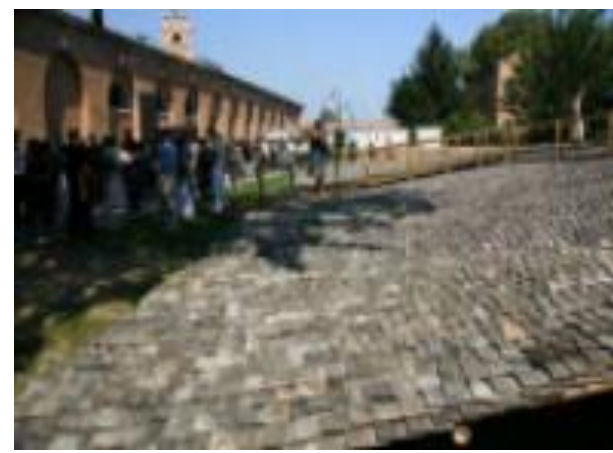

Figure4 "TILES GARDEN" 
Both the Wa of Xiangshan campus and "TILES GARDENS" at THE VENICE BIENNALE, are originated from folk craftsmanship. There are two ways of using tiles in Xiangshan Campus, the first one is using as roof or overhanging eave, while it could do a slight improvement in the paved method. For instance, on the canopies, black tiles are paved to face upside and down, then placed directly on the bamboo veneer. Two more wa are added on the end and the top to serve as the end and coping. Wa are connected with the bamboo veneer through cement mortar, and the bamboo veneer is supported by a steel keel(Figure 7).
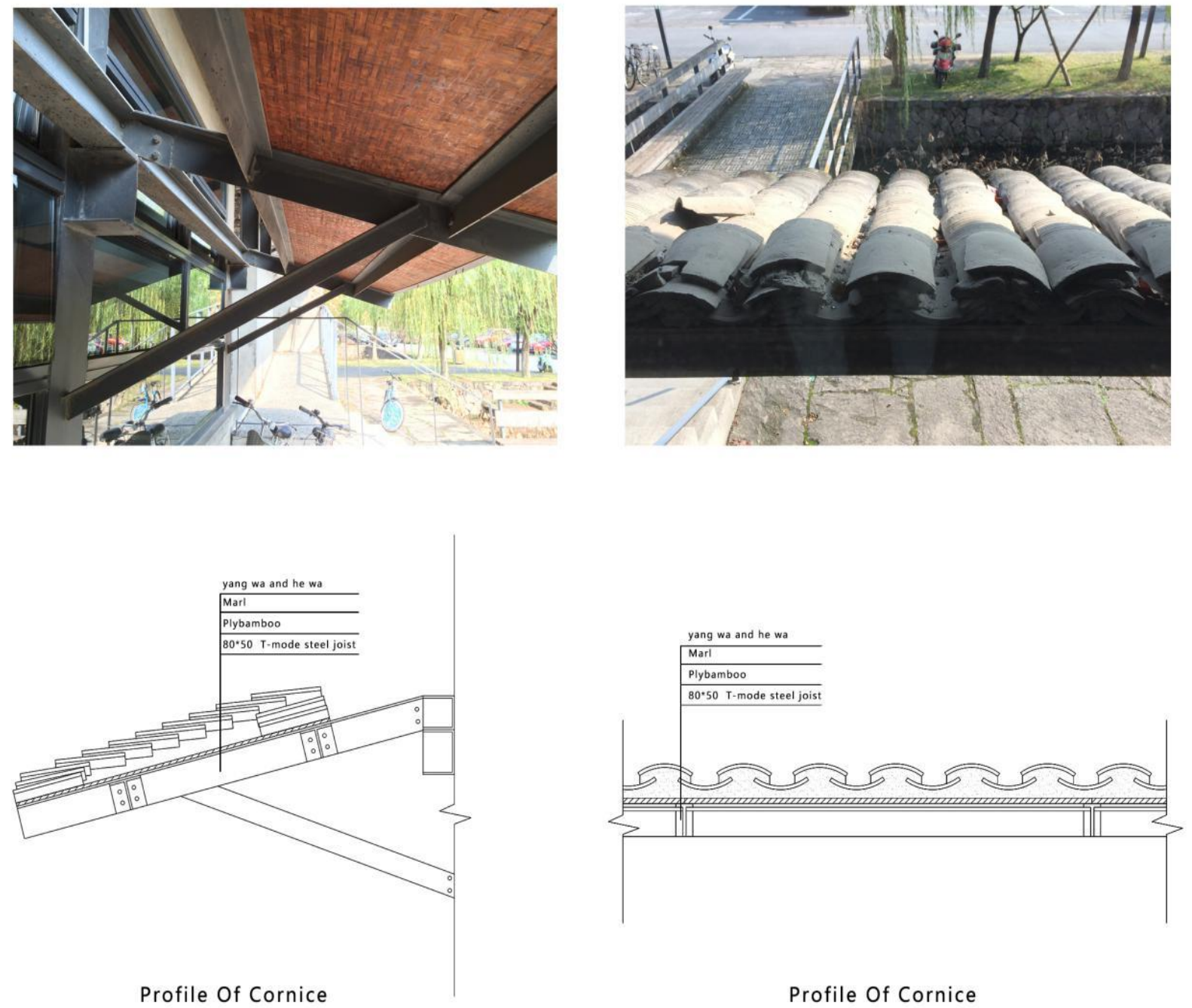

Pic 7 Details of Cornices

The other is as a masonry material, called "wapan" wall(瓦仯墙 ${ }^{13}$, which using the unique craft in Zhejiang Province-"building techniques of picking up broken bricks and wa"(Figure5,6).The "wapan" wall is used as the facade of the teaching building in Xiangshan Campus, a technique also used on the exterior wall of Ningbo Museum. In the "TILES GARDEN", bamboo stems bear wa, which are formed by bundling. The bamboo stems replace the traditional rafters and purlins, and the construction craft of wa in the "TILES GARDEN" is much closer to the traditional construction technology (Figure 8).

\footnotetext{
${ }^{13}$ Wanpan wall(瓦墙 :Wapan wall is a kind of wall that made of masonry by layers of craft, and created in east Zhengjiang Province. Folk craftsmen adopt waste building matericals such as old wa, old bricks as main material, then use yellow mud or yellow mud with lime as supplementary to bond.
} 


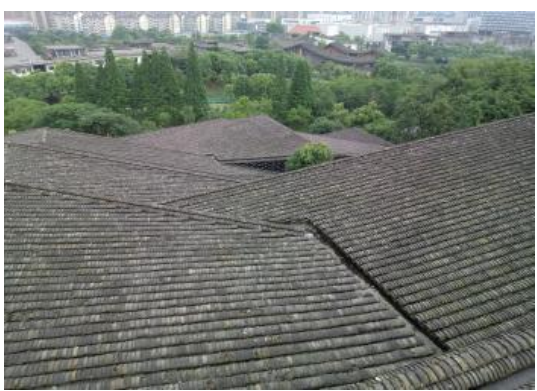

Figure 9 The roof of The Folk Art Museum of China Academy of Art

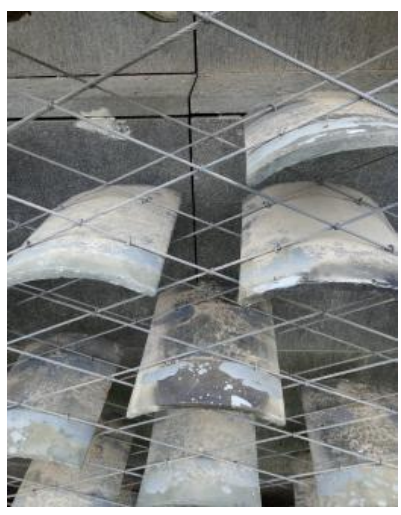

Figure11 Details of Wa's constriction of The Folk Art Museum

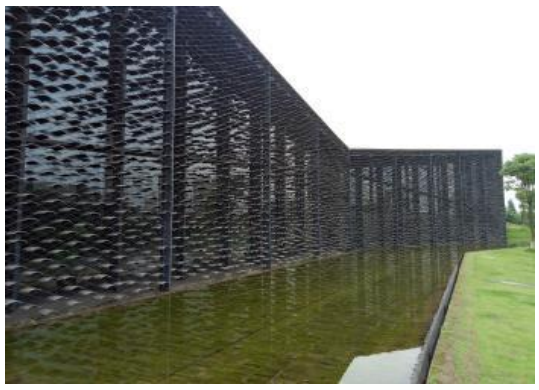

Figure 10 The shell ofThe Folk Art Museum of China Academy of Art

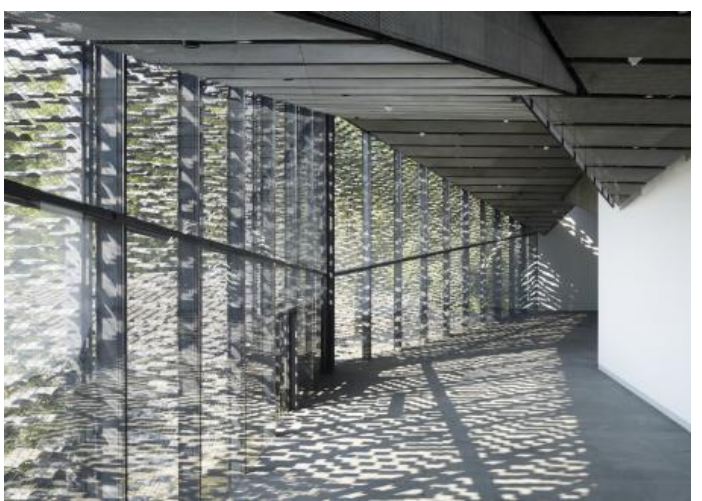

Figure12 Lights and shadows inside the building

It is not hard to find that Wang Shu's wa is the inheritance of traditional tile-work craft, and is closer to the original tile. As the "pensiero debole" believes which is an Italian school of thought, tradition is a kind of constantly evolving complex, as the foundation of materialization and ideological realization of the living world, also tradition helps to make up for the deficiency of instrumental rationality. The transcendental value of the traditional tile-work has become the source of Wang Shu's creation.

In Xiangshan Campus, wa is more like a carrier of cultural and technological inheritance and innovation to Wang Shu. Layers of tile eaves of the teaching building are the symbol of Chinese architecture, they strengthen the horizontal trend of the architectural group, and to compare with mountains, also show a traditional Chinese meaning of “urban mountains and forests"(城市山林). The “wapan" wall of the teaching building is a creation of turning old Wa from different eras which could be abandoned as trash into a whole wall, using them recycling and effectively controlling the cost. The black bricks with wearing and wearing by time, came to Xiangshan Campus with imprints of time, also treat present time and the past as juxtaposition, "when the new building was built, it already had decades or even hundreds years of history.". The "wapan"wall has also become Wang Shu's signature architectural vocabulary. The "TILES GARDEN" shows that Wa is the expression of the image of traditional culture and the medium of cultural communication. Half of them were being paved, the rest were being set along the diagonal to a slope, formed a giant “contrary flexure roofing”(反曲屋面). “TILES GARDEN” seems like a platform, walking upon it, to become a Chinese park with brand-new consciousness. Renato, the general technical superintendent of the Venice Biennale, walked back and force on the bamboo bridge in the "TILES GARDEN", said sincerely to Wang Shu, "That's really a wonderful work." The funniest thing is, to him there is no such thing called "Chinese Tradition", he only appreciates Wang's works that are customized for Venice. The large roofing just like a mirror, also like the ocean water of Venice, it reflected buildings, skies and trees. Coincidentally, for the original idea of “TILES GARDEN", indeed, it has the artistic conception of water"水意” as Dong Yuan thought which lived in Five Dynasties. 
Wang Shu chose to inherit traditional craft in his exploration of the tectonic of Wa's contemporary context. One side, Wang Shu's design ideal starts from the ideology of natives, and take root in local, also he likes to choose local materials and build modes. Wa, as a local material and construction mode, it's chose and applied by Wang Shu. So he tried to find an effective and professional construction method, and tried to promote it on a large scale which is emphasizing a collective operate mode with handmade construction as the core method. His attempt is an innovation for finding an exit for the problem that traditional Chinese craftsmanship cannot be built on a large scale. On the other side, Wang Shu explored traditional spiritual tectonic in virtue of wa's traditional construction methods. As a modern annotation of the spirit to Chinese literati, the old wa with time traces is the carrier of history and traditional craft and arts.Meanwhile, it is the living places constructed by the irreplaceable wa, and rooted deeply in Chinese people's mind. Wang Shu has found a new home for the old wa, and a shelter for our memory of tradition. The old wa has been revitalized in the buildings which designed by Wang Shu. Traditions are being passed on and reborn.

\subsection{Exploration of Contemporary spirituality in wa's tectonic culture by creating new construction}

If Wang Shu's exploration of wa is a traditional spiritual exploration based on the traditional construction craft of wa, then Kengo Kuma and Zhang Yonghe's exploration of wa are more focused on the possibility of the form tectonic of modernity(现代生形式建松) of wa. It did not directly pursue the inheritance of traditional craftsmanship of wa, but regarded wa as an abstract symbol and combined with modern architectural technology and new materials to form a new kind of architecture with special interest mixes by tradition and modernity.

In the folk art museum of China Academy of Art, which was completed in 2015, Kengo Kuma applied wa element to the roof and the museum's shell(表皮)(Figure9, Figure 10). The steel rope structure is used to fix the placement of wa on the shell of the building, which makes wa "floating up", just like scales, showing a sense of beauty in vision. Meanwhile, it also effectively controls the illumination, making the whole space appear transparent and presenting the effect of lights and shadows(Figure11, Figure12). The original site was a tea garden on a hillside. The ups and downs of the architecture were built according to the shape of the mountain. The scattered roofs and black tiles together can evoke people's memory of traditional wa. The designer wanted the architecture to have both the traditional architectural language and the characteristics of modern architectures. In the construction of the surface, wa is only a symbolic element on the surface, but did not participate in building the structure, or forced by other forms.

In 2010, Zhang Yonghe took "wa-light" as his theme in the "life exhibition of China, Korea and Japan" in the Seoul Design Festival of South Korea. He built two "tea booths" with two arches to provide a place that can rest and communicate for families and friends(Figure 13). Zhang Yonghe tookround tiles, which was pierced and fastened with bolts on each piece of round tiles, and then formed a pointed arch with the steel cable connecting bolts. Each wa arch unit was connected into an arch surface through the transverse keel(Figure 14, Figure 15). Like other masonry material, Wa typically express heaviness, but now architects are trying to give this ancient material a new interpretation. That is light. At this moment, wa is no longer a part of roofing, it becomes a factor of structure.

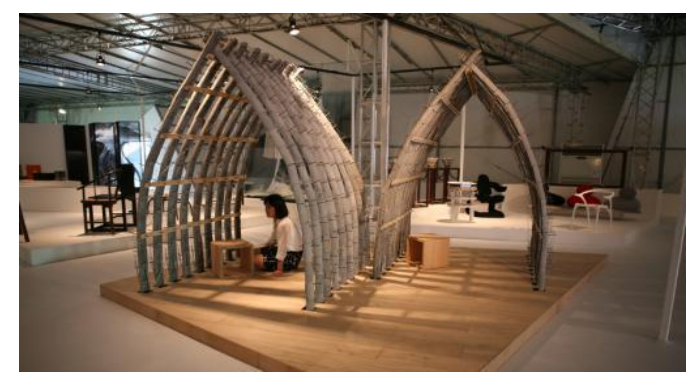

Figure 13 "Wa-light"

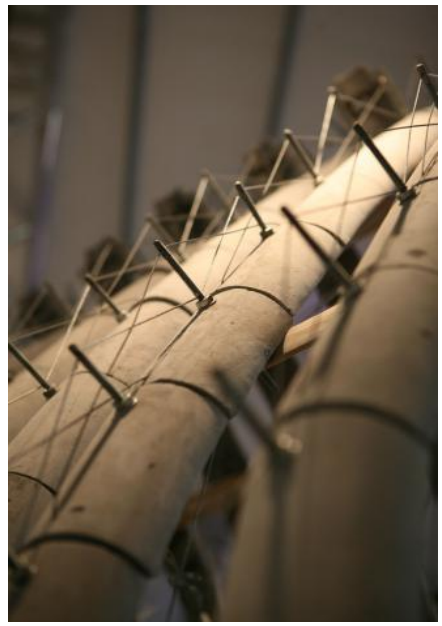

Figure 14 Details of Structure of "Wa-light" 


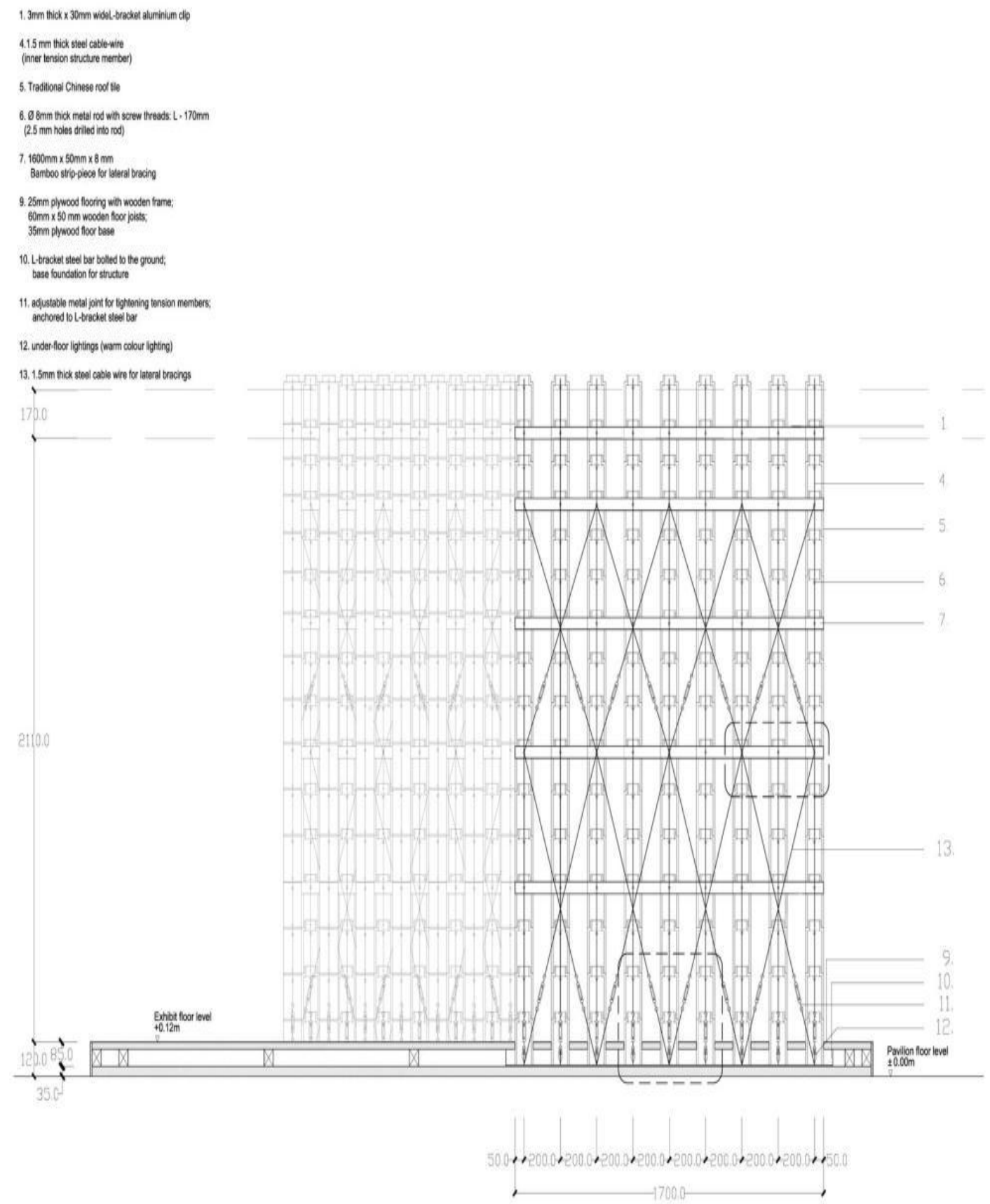

Figure 15 Structure diagram of "Wa-light"

The explorations of Kengo Kuma and Zhang Yonghe provided new ideas for the exploration of the tectonic in contemporary context for wa. Wa could still be wa, could it be something else? The roof? The structure? The shell? In the folk art museum of China Academy of Art, wa as the shell of the building is a creative application of architecture. As in "Wa-light", as a spatial construction material, wa combines with modern materials and cable structure to become a part of the supporting structure. Those two architects attached great importance to the new opportunities of wa's tectonic in the contemporary context. Their re-thinking of the possibility of wa's tectonic mode gave wa itself new, rich and diverse possibilities, which refreshed our understanding of wa. 


\subsection{Exploration of Traditional Chinese spirituality in wa's tectonic culture by stripping noumena of Wa}

By the reason of the limitations of wa's processing methods, there are some difficulties for industrialization scale production. Our insistence on the study of wa is probably more about the traditional Chinese cultural connotation and historical memory that wa's image contains. So, is there any possibility that in contemporary context wa could be translated? In 2013, about the studying of wa, Qian Qiang opened up a new method by his project'Shui Yue Zhouzhuang". This new method is exploration of wa's spirit - stripping Wa's noumena materiality.

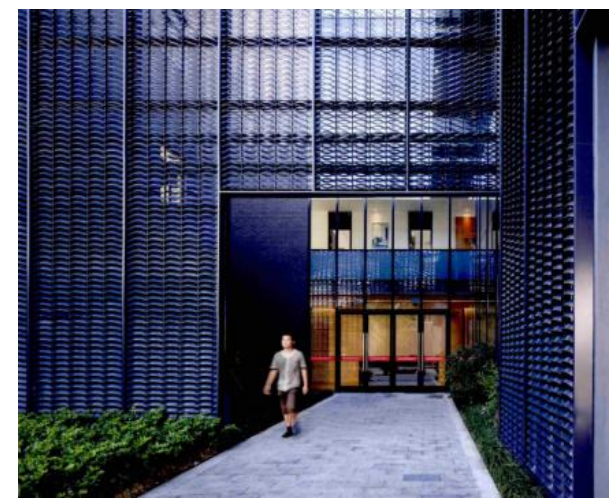

Figure 16 Vertical face of "liwa"

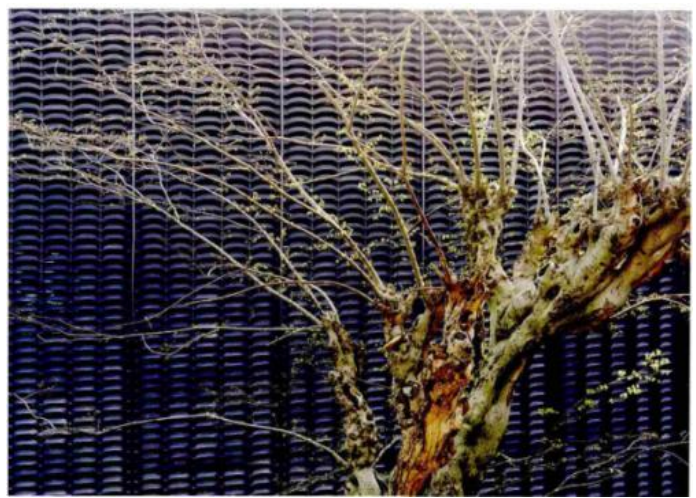

Figure 17 View the elevation from the courtyard

In the sales department and facades of the office building of his project "Shui Yue'Zhouzhuang", Qian Qiang used his new patent "liwa"(离瓦)【 Note:patent for utility models(patent No.ZL 20132 0434825.5), registration of design(patent No.ZL 20133 0341270.5)】(Pic 16, Pic 17).In the new project, the architect hopes to find a new material and new technology to express the traditional form and image of the blackwa, and to be able to industrialize scale production. Through repeated analysis by sketches, paper models and CAD modelings, and continuous discussion and cooperation with curtain wall companies, they finally developed "liwa". "Liwa" is adopted with $2 \mathrm{~mm}$ in thickness fluorocarbon coated aluminum plate whose surface it cut discontinuously. Then two sides were pushed up and down and stamped to form a natural arc, to established a whole molding at one time. It fastened and connected by horizontal and vertical components and fittings.

This kind of "liwa" made of modern industry standardization production technology which can be used as exterior wall louver, has the function as ventilation, heat insulation and sunshade. It can also be assembled in small unit, and easy to install and disassemble, has a wide range of applications(Figure18,19,20).The "liwa" creatively applies the traditional image of Jiangnan famous black wa to the facade of a building. At the same time, by controlling the size of discontinuous cutting and fixed angle of inclination, to achieved different permeability so it can form an abundant light and shadow effect of interior.

Qian Qiang's "liwa" provides a new idea of inheritance and regeneration of Chinese tile-work, which has two meanings. The first one is material conversion: the conversion of traditional wa which made of clay into industrial material, and it's easy to start large-scale production. The second one is, change of built mode: using modular assembly, adapting to modern construction mode, and providing efficiency. Architects think deeply and diversely about the inheritance and regeneration of traditional elements like wa and try to discover various possibilities of traditional elements. New materials, new technologies and new construction can be considered as new attempts.

\section{Conclusions}

China is an ancient country with a long history and splendid cultural traditions. Chinese contemporary architecture should not only pursue modernity and embody the spirit of the age, but also combine its rich diversity cultural traditions. Therefore, under new circumstances, how to incarnate cultural tradition of architectures, how to apply the traditional elements and construction techniques that are still of great practical value are an important task of contemporary Chinese architectural creation.

Architects have made great efforts to discuss wa, as a traditional Chinese element with splendid cultural connotation, and significance in both technical and cultural aspects of tile-work is constantly changing(Figure 21). In the contemporary context, the response of Wang Shu to the construction of wa element is to choose to inherit the traditional constructing methods and to build the traditional spirit. 
The response of Kengo Kuma and Zhang Yonghe to the construction of wa element is to choose to explore the possibility of the modernity of modality tectonic of wa instead of inheriting traditional techniques of tile-work. Moreover, the response of Qian Qiang to the tectonic of wa element is to explore the possibility of transferring wa element to modernization. They are making efforts to explore the tectonic of wa element in the contemporary context(Chart 2).

\begin{tabular}{|c|c|c|c|c|c|c|}
\hline $\begin{array}{l}\text { A Preliminary } \\
\text { Study of } \\
\text { Construction in } \\
\text { contemporary } \\
\text { context of } \\
\text { Chinese } \\
\text { Traditional - Wa } \\
\text { Element }\end{array}$ & \multicolumn{3}{|c|}{$\begin{array}{l}\text { Exploration of Traditional Chinese spirituality in wa's } \\
\text { tectonic culture by traditional tile-work }\end{array}$} & \multicolumn{2}{|c|}{$\begin{array}{l}\text { Exploration of } \\
\text { Contemporaryspirituality in wa's } \\
\text { tectonic culture by creating new } \\
\text { construction }\end{array}$} & $\begin{array}{l}\text { Exploration of Traditional Chinese } \\
\text { spirituality in wa's tectonic culture by } \\
\text { stripping noumena of Wa }\end{array}$ \\
\hline \multirow{2}{*}{$\begin{array}{l}\text { Representative } \\
\text { architects and } \\
\text { their Magnum } \\
\text { opus }\end{array}$} & \multicolumn{3}{|l|}{ Wang Shu } & Kengo Kuma & Zhang Yonghe & Qian Qiang \\
\hline & \multicolumn{2}{|c|}{ Xiangshan Campus of CAA } & $\begin{array}{l}\text { The installation } \\
\text { at Venice } \\
\text { Biennal-“Tiles } \\
\text { Garden",2006 }\end{array}$ & $\begin{array}{l}\text { The folk arts } \\
\text { Museum of } \\
\text { Xiangshan } \\
\text { Campus of CAA }\end{array}$ & $\begin{array}{l}\text { "Wa- } \\
\text { light",Seoul } \\
\text { Design } \\
\text { Festival,2010 }\end{array}$ & $\begin{array}{l}\text { The sales apartment of "Shuiyue } \\
\text { Zhouzhuang" }\end{array}$ \\
\hline $\begin{array}{l}\text { The position or } \\
\text { function of a } \\
\text { building }\end{array}$ & $\begin{array}{l}\text { as one of the } \\
\text { construction } \\
\text { materials, } \\
\text { using for the } \\
\text { surface }\end{array}$ & $\begin{array}{l}\text { Roof or } \\
\text { cornice }\end{array}$ & $\begin{array}{l}\text { Wa roofing, also } \\
\text { construct the site }\end{array}$ & $\begin{array}{l}\text { as building } \\
\text { material for the } \\
\text { surface }\end{array}$ & $\begin{array}{l}\text { as a part of the } \\
\text { structure, take } \\
\text { part in spacial } \\
\text { construction }\end{array}$ & as the shell of a building \\
\hline $\begin{array}{l}\text { Materials and } \\
\text { Size }\end{array}$ & $\begin{array}{l}\text { Traditional old } \\
\text { black } \\
\text { tiles, } 200 * 150\end{array}$ & $\begin{array}{l}\text { Traditional old } \\
\text { black } \\
\text { tiles, } 200^{*} 150\end{array}$ & $\begin{array}{l}\text { Traditional old } \\
\text { blue } \\
\text { tiles, } 200 * 150\end{array}$ & $\begin{array}{l}\text { Specially made } \\
\text { black tiles, } \\
270 \mathrm{~mm}^{*} 210 \mathrm{~mm}\end{array}$ & $\begin{array}{l}\text { Round tiles, } \\
8 * 110 * 160\end{array}$ & $\begin{array}{l}\text { "liwa",2mmin thickness fluorocarbon } \\
\text { coated aluminum plate whose surface is } \\
\text { cut discontinuously. }\end{array}$ \\
\hline $\begin{array}{l}\text { Fasten Method } \\
\text { or detail }\end{array}$ & $\begin{array}{l}\text { "wapan"wall, } \\
\text { an unique } \\
\text { construction } \\
\text { techniques in } \\
\text { Zhejiang,the } \\
\text { art of using } \\
\text { broken wa and } \\
\text { bricks. Using } \\
\text { cement mortar } \\
\text { to built. }\end{array}$ & $\begin{array}{l}\text { Blue tiles are } \\
\text { bent over and } \\
\text { placed directly } \\
\text { on the bamboo } \\
\text { veneer. Wa are } \\
\text { connected with } \\
\text { the bamboo } \\
\text { veneer through } \\
\text { cement mortar, } \\
\text { and the } \\
\text { bamboo } \\
\text { veneer is } \\
\text { supported by a } \\
\text { steel keel. }\end{array}$ & $\begin{array}{l}\text { Two wa are } \\
\text { paved to face } \\
\text { upside and } \\
\text { down,then } \\
\text { placed directly } \\
\text { on bamboo. }\end{array}$ & $\begin{array}{l}\text { The steel rope } \\
\text { structure is used } \\
\text { to fix the } \\
\text { placement of wa } \\
\text { on the shell of the } \\
\text { building. }\end{array}$ & $\begin{array}{l}\text { Each round } \\
\text { tile was } \\
\text { pierced and } \\
\text { fastened with } \\
\text { bolts on } \\
\text { another and } \\
\text { then formed a } \\
\text { pointed arch } \\
\text { with the steel } \\
\text { cable } \\
\text { connecting } \\
\text { bolts. Each } \\
\text { arch unit of } \\
\text { wa was } \\
\text { connected into } \\
\text { an arch surface } \\
\text { through the } \\
\text { transverse } \\
\text { keel. }\end{array}$ & $\begin{array}{l}\text { It can also be assembled in small unit, and } \\
\text { easy to install and disassemble. }\end{array}$ \\
\hline Significance & \multicolumn{2}{|c|}{$\begin{array}{l}1 \text { For the inheritance of } \\
\text { traditional wa craftsmanship, } \\
\text { trying to find an exit for the } \\
\text { problem that traditional Chinese } \\
\text { craftsmanship cannot be built on } \\
\text { a large scale. } \\
2 \text { Traditional spiritual } \\
\text { construction is explored by } \\
\text { means of wa's traditional } \\
\text { construction. }\end{array}$} & $\begin{array}{l}1 \text { a display of } \\
\text { traditional skills; } \\
2 \text { a medium of } \\
\text { international } \\
\text { communication }\end{array}$ & \multicolumn{2}{|c|}{$\begin{array}{l}\text { To make a new definition of wa's } \\
\text { function, in the contemporary } \\
\text { context, looking for wa's modernity } \\
\text { form construction }\end{array}$} & $\begin{array}{l}1 \text { to convert materials } \\
2 \text { mass production } \\
3 \text { shifting of construction mode, modular } \\
\text { assembly }\end{array}$ \\
\hline Inadequacies & \multicolumn{2}{|c|}{$\begin{array}{l}\text { 1The combination of traditional } \\
\text { techniques and modern } \\
\text { architecture still needs to be } \\
\text { discussed, and some details are } \\
\text { rough. } \\
2 \text { It costs a lot of manpower,and } \\
\text { it's not suitable for popularized. }\end{array}$} & \multicolumn{2}{|c|}{$\begin{array}{l}\text { It only uses the symbolic of wa, but } \\
\text { does not use the stress, waterproof } \\
\text { function of wa. }\end{array}$} & $\begin{array}{l}\text { Making wa as } \\
\text { a part of the } \\
\text { spacial } \\
\text { structure, will } \\
\text { the traditional } \\
\text { meaning of wa } \\
\text { itself be } \\
\text { deprived? }\end{array}$ & $\begin{array}{l}\text { Should the modern representation of wa } \\
\text { be faithful to the natural attributes of the } \\
\text { material? }\end{array}$ \\
\hline
\end{tabular}

Chart 2 The contrast diagram of construction exploration in the contemporary context of wa element

However the path to modernization of wa element is beast with difficulties. Is there a more detailed optimization of traditional craft in pursuing the traditional livelihood image and directly inherit traditional wa technologies, but without the construction of rough details? After using the modern new technology of the mode of construction, 
willthe traditional meaning of black tile itself be deprived? Is "liwa" the one which through the conversion of materials and technologies that really achieved the goal that can carrying the traditional image ? Should the modern representation of wa be faithful to the natural attributes of the material? All of these questions need generations of architects to think constantly of, and to explore continuously.

\section{References}

\section{Reference to a book}

弗兰普顿 (2007). 建松文化研究 中国建筑工业出版不土.

梁思成 (1983). 营造去式注释. 中国建筑工业出版不土.

梁思成 (2006). 清式营造川峢 清华大学出版不土.

中国科学院自然科学史研究所. (1985). 中国古代建筑技术史. 科学出版社

张至冈川蹭编 (1986). 营造去原 中国建筑工业出版社.

Reference to a journal publication

钱虽 (2014). 传统空间语言的现代转化-水月周庄一期项目. 建筑技艺(7), 66-75.

王澍＆陆文宇. (2008). 中国美术学院象山校区 建筑学报(9), 50-59.

王澍，\&陆文宇 (2008). 营造恍记 建筑学报(9), 50-59.

张或 \& 李佳颖 (2018). 瓦在现代语竟下的建松初探 城市建筑(4).

Reference to Web Source

https://www.archdaily.cn/cn/757104/wa-light-fei-chang-jian-zhu-gong-zuo-shi 